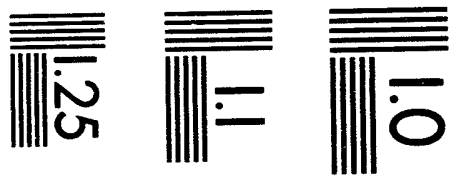

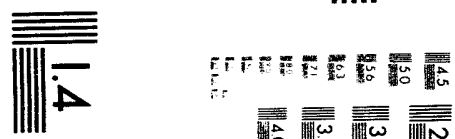

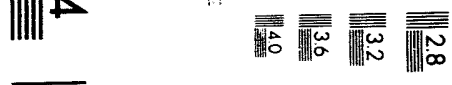

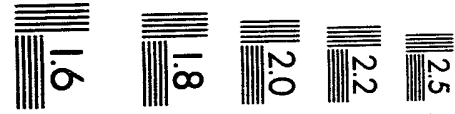



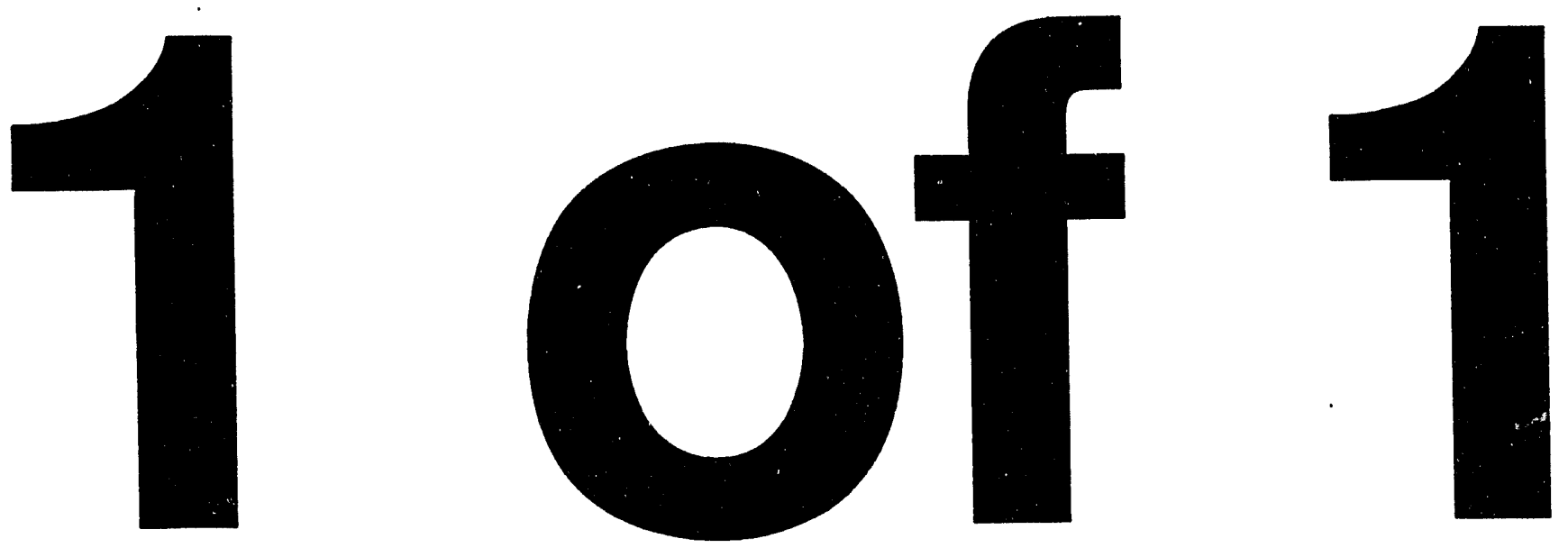


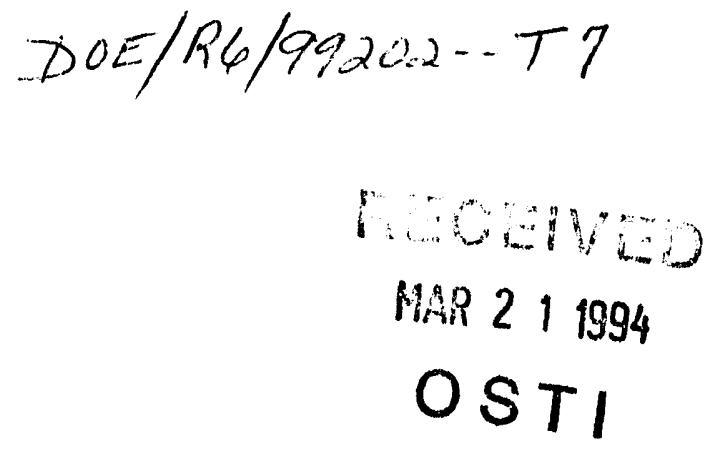

GEOHYDROLOGICAL FEASIBILITY STUDY OF THE BLACK WARRIOR BASIN FOR THE POTENTIAL APPLICABILITY OF JACK W. MCINTYRE'S PATENTED PROCESS

By

P. Damian Reed

March 1994

Work Performed Under Jack Mcintyre/DOE Contract No. DE-FG46-92R699202

For

Jack W. Mcintyre

Fort Stockton, Texas

And

U.S. Department of Energy

Office of Scientific and Technical Information (OSTI)

Oak Ridge, Tennessee

By

Geraghty \& Miller, Inc.

Midland, Texas

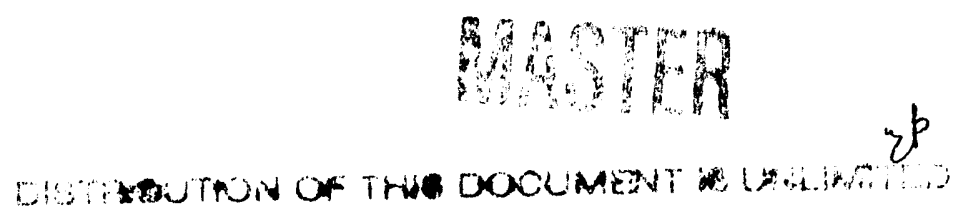




\section{CONTENTS}

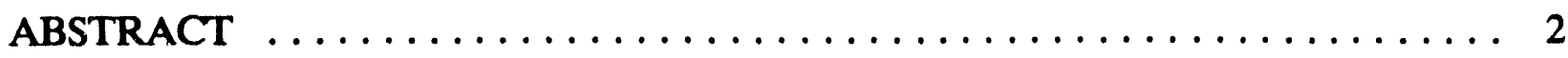

INTRODUCTION $\ldots \ldots \ldots \ldots \ldots \ldots \ldots \ldots \ldots \ldots \ldots \ldots \ldots \ldots \ldots \ldots \ldots \ldots \ldots, 2$

STRUCTURE AND STRATIGRAPHY $\ldots \ldots \ldots \ldots \ldots \ldots \ldots \ldots \ldots \ldots$

GENERAL ........................... 5

PRECAMBRIAN TO DEVONIAN $\ldots \ldots \ldots \ldots \ldots \ldots \ldots \ldots \ldots \ldots, 6$

MISSISSIPPIAN $\ldots \ldots \ldots \ldots \ldots \ldots \ldots \ldots \ldots \ldots \ldots \ldots, 8$

Tuscumbia Formation $\ldots \ldots \ldots \ldots \ldots \ldots \ldots \ldots \ldots, \ldots$

Monteagle Limestone $\ldots \ldots \ldots \ldots \ldots \ldots \ldots \ldots \ldots \ldots, 9$

Pride Mountain Formation $\ldots \ldots \ldots \ldots \ldots \ldots \ldots \ldots, 9$

PENNSYLVANLAN

Structure .......................... 11

Stratigraphy of Coal-Bearing Rocks (Pottsville) $\ldots \ldots \ldots \ldots \ldots, 15$

COAL AND COALBED METHANE - OCCURRENCE AND

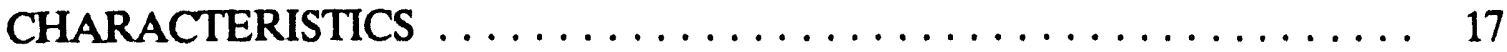

COAL OCCURRENCE $\ldots \ldots \ldots \ldots \ldots \ldots \ldots \ldots \ldots \ldots \ldots, 17$

COALBED METHANE OCCURRENCE

Wartior Coal Field $\ldots \ldots \ldots \ldots \ldots \ldots \ldots \ldots \ldots \ldots, 24$

Cahaba Coal Field $\ldots \ldots \ldots \ldots \ldots \ldots \ldots \ldots \ldots \ldots \ldots \ldots \ldots \ldots \ldots$

HYDROLOGY AND RESERVOIR CHARACTERISTICS $\ldots \ldots \ldots \ldots 28$

Permeability/Porosity ....................... 28

Cleat and Joint Orientation $\ldots \ldots \ldots \ldots \ldots \ldots \ldots \ldots \ldots . \ldots 29$

COALBED METHANE DEVELOPMENT AND PRODUCTION IN THE

BLACK WARRIOR DEGASIFICATION FIELDS $\ldots \ldots \ldots \ldots \ldots, 32$

Coalbed Methane Production .................. 32

Coalbed Methane Produced Water Discharge Regulations in Alabama ........................... 33

Water Quality Criteria ..................... 34

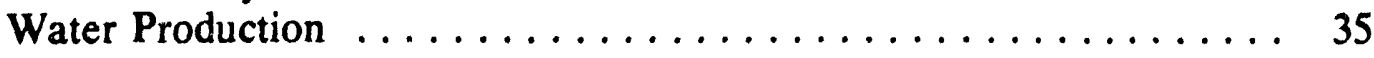

Water Quality ......................... 35

Pretreatment Before Discharge $\ldots \ldots \ldots \ldots \ldots \ldots \ldots \ldots \ldots, 36$

ACKNOWLEDGEMENT $\ldots \ldots \ldots \ldots \ldots \ldots \ldots \ldots \ldots \ldots \ldots \ldots \ldots$ 


\title{
GEOHYDROLOGICAL FEASIBILITY STUDY OF THE BLACK WARRIOR BASIN FOR THE POTENTIAL APPLICABILITY OF JACK W. MCINTYRE'S PATENTED PROCESS
}

\begin{abstract}
Geraghty \& Miller, Inc. of Midland, Texas conducted geological and hydrological feasibility studies of the potential applicability of Jack W. McIntyre's patented process for the recovery of natural gas from coalbed/sand formations in the Black Warrior Basin of Mississippi and Alabama through literature surveys. Methane gas from coalbeds in the Black Warrior Basin is confined to the coal fields of northern Alabama. Produced water from degasification of coalbeds is currently disposed by surface discharge. Treatment prior to discharge consists of short-term storage and in-stream dilution.
\end{abstract}

Mr. McIntyre's process appears to be applicable to the Black Warrior Basin and could provide an environmentally sound alternative for produced water production.

\section{INTRODUCTION}

Producing gas wells completed in coalbeds typically produce methane and wastewater (brine). The produced water in the Black Warrior Basin is commonly treated by utilizing short-term storage and in-stream dilution (Luckianow and Hall 1991). This approach is governed by stream flow variability, production water flow characteristics and the economics of storage and construction. Also, environmental regulations pertaining to the release of 
wastewater to surface waters of the United States is presently under government investigation.

A new process by Jack McIntyre has both economic and environmental advantages over the conventional storage and surface discharge of production water. Mr. McIntyre's process has been tested in the Michigan Basin and reported to be successful. The process is based on utilizing a single well for both production and subsurface water disposal. During production, fluids enter the well bore, the gas rises to the surface and the production water moves down into the disposal zone either by gravity or mechanical pumping. This method allows separation of gas with simultaneous disposal of the water without the economic and environmental obstacles of bringing the water to the surface. A description and discussion of Jack McIntyre's process is summarized in the compendium of the seven basins studied under this contract.

The objective of this investigation was primarily to identify the geologic and hydrologic parameters associated with the production of coalbed methane in the Black Warrior Basin of Mississippi and Alabama for the potential use of Jack McIntyre's patented process. The investigation includes the description of geological formations in ascending order, the present day structure of each formation, the stratigraphy of each formation as it applies to potential methane gas production and water disposal, hydrologic conditions (formation pressure, fluid chemistry, etc.) and reservoir and production history. Published papers and reports were the primary sources of information utilized for this investigation. 
No field acquisition of data was performed during this investigation nor has Jack McIntyre's process been tested in the Black Warrior Basin.

The Black Warrior Basin or the Warrior Basin is one of the principal coalbed methane basins in the continental United States. The Warrior Basin has been studied extensively through Gas Research Institute (GRI) funding for multiple coalbed characterization, production and well technology for commercial applications (GRI Quarterly Review February 1987). Coalbed gas drilling in the Black Warrior Basin has resulted in average gas production ranging from 20 MCFD in 1980 to over 235 MMCFD in 1992 (GRI Quarterly Review February 1987; Kuuskraa et al. 1992).

\section{GEOLOGIC SETTING}

The Black Warrior Basin is located in northeastern Mississippi and northwestern Alabama and covers an area of approximately 35,000 square miles. Figure 1 (GRI Quarterly Review March 1990) shows the general location of the basin. The basin is structurally bounded on the north by the Nashville-Cincinnati arch and on the southeast by the Appalachian fold and thrust belt. The Black Warrior Basin physiographically straddles the Cumberland Plateau, Appalachian Valley and Ridge province and the East Gulf Plain (Thompson and Telle 1987). The basin is largely covered by Cretaceous and younger sediments of the Gulf Coastal Plain and Mississippi Embayment, but it is believed to be 


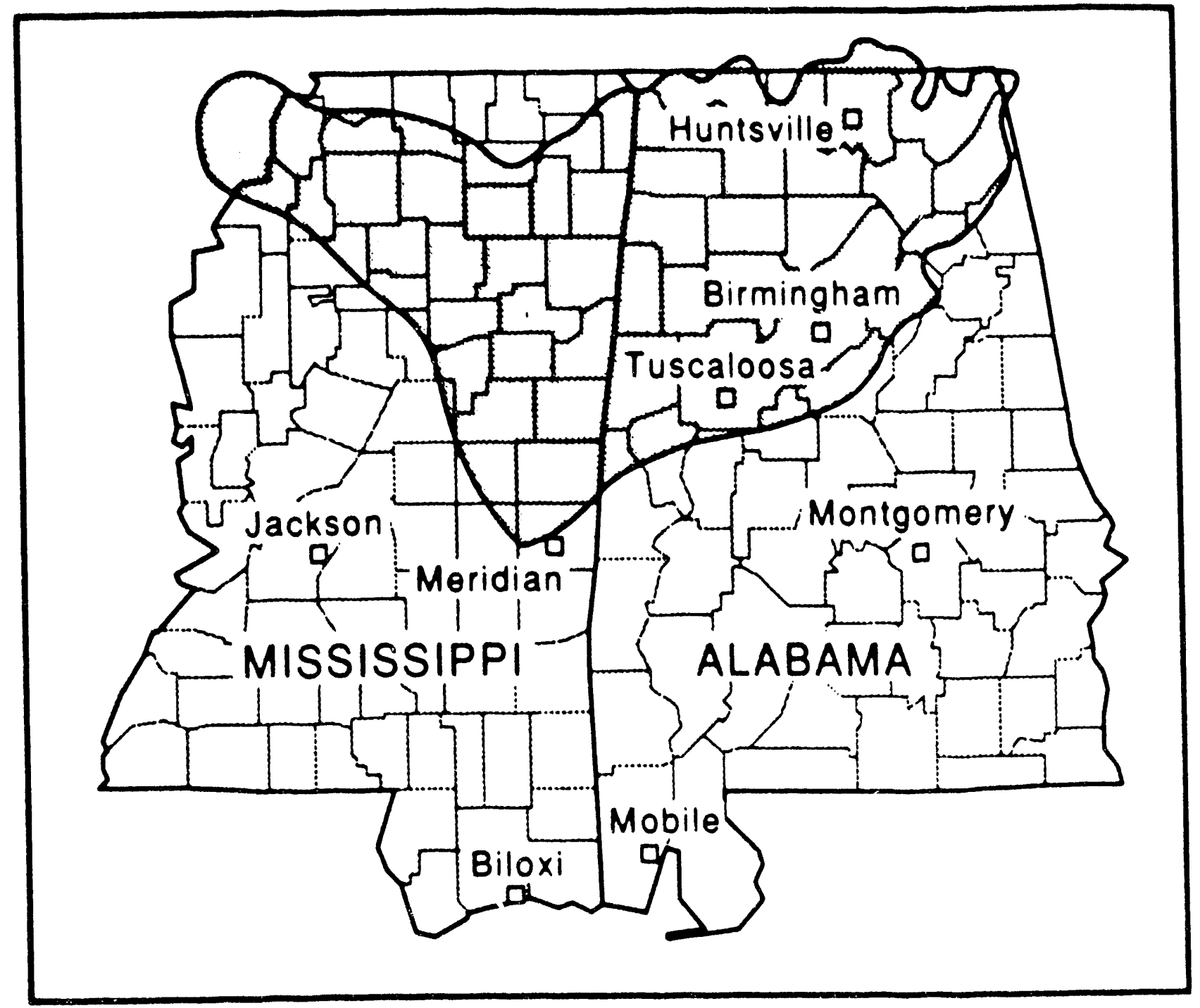

\section{Location}

West-central Alabama and east-central Mississippi

Figure 1. Geographic Location of the Black Warrior Basin (after GRI Quarterly Review March 1990). 
continuous in the subsurface with the Arkoma Basin of Arkansas and Oklahoma to the west. Pre-Pennsylvanian strata of the Ouachita fold belt which mark the southwestern basin boundary in Mississippi possibly extend into Alabama (Flawn et al. 1961; Thompson and Telle 1987). The uppermost strata of the Black Warrior Basin are predominantly coalbearing Pottsville Pennsylvanian-age formation sedimentary rocks. This strata overlies a thick sequence of Lower Cambrian to Upper Mississippian sedimentary rocks (Figure 2). The Pottsville Formation represents the youngest known Paleozoic sedimentation in the basin. Equivalent Paleozoic rocks of younger Pennsylvanian strata which are found in the Appalachian Basin to the east apparently are absent here. Pottsville strata are unconformably overlain by sediments no older than Late Cretaceous (Thompson and Telle 1987).

\section{STRUCTURE AND STRATIGRAPHY}

\section{GENERAL}

The Black Warriot Basin is roughly triangular in shape and is filled primarily with sediments of Mississippian and Pennsylvanian ages. The triangular shape is formed by the Paleozoic rocks that create the basin's boundaries. The northern boundary is formed by the Ozark Uplift to the northwest and the Nashville Dome to the northeast. The basin is bounded to the east and southeast by the southwesterly plunging folds and steeply overturned beds of the Appalachian system. The deeply buried Ouachita fold and thrust 
belt defines the basin's western and southwestern limits. The greater part of the basin's triangular area is overlapped by Mesczoic and Tertiary age sediments of the Gulf Coastal Plain. These sediments are more than 6,000 feet thick in central Mississippi and form discontinuous outliers capping ridges and hills in central and western Alabama (Self and Neathery 1975; Kidd 1976). Figure 2 (Beg et al 1978) represents the broad stratigraphy of the Black Warrior Basin.

\section{PRECAMBRIAN TO DEVONIAN}

Early Paleozoic-age rocks are exposed in a few places on the basin's boundaries. Precambrian granites have been found at depths of slightly less than 6,000 feet in Tennessee on the Nashville Dome. It is thought that these granites were eroded long ago to produce thick wedges of sandstones lying deep within the Warrior Basin (Mellen 1971). These granites are exposed in eastern Alabama and Tennessee and are highly contorted and metamorphosed with evidence of having been porous and bituminiferous (Butts 1926; Mellen 1947).

Cambrian and Ordovician carbonate units were deposited on a stable shelf environment as the seas transgressed from the southeast. Toward the west and northwest, the carbonates are overlain by and interfinger with clastics derived from the west (Boland and Minihan 1971; Milici et al. 1973). 


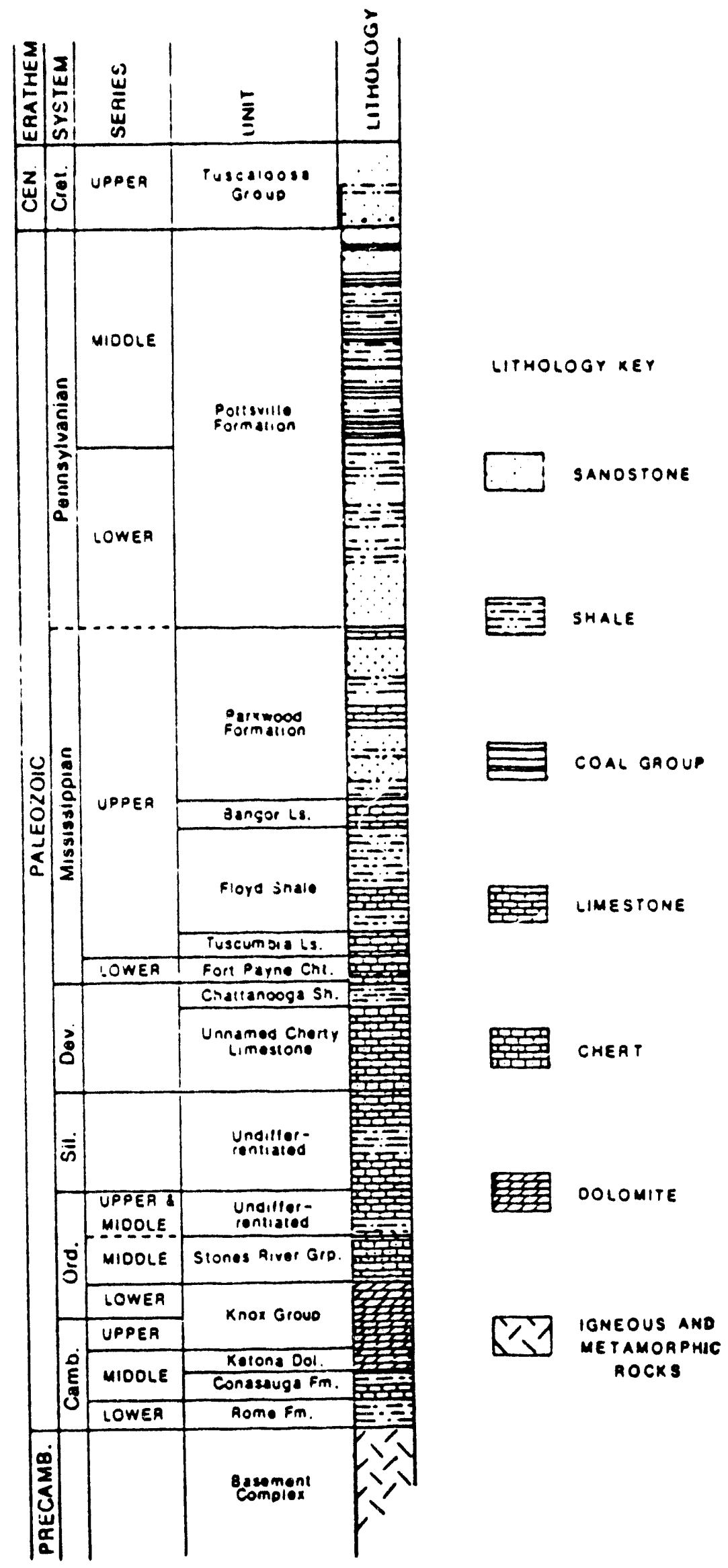

Figure 2. Generalized Stratigraphy of the Black Warrior Basin (after Beg and Others 1978). 
Silurian-age deposits in the Black Warrior Basin are composed primarily of interbedded seams of red fossil ore of the Red Mountain Formation. This ore accumulated through chemical replacement of extensive beds of fossil fragments by iron rich waters (Butts 1926). Porous reef-type accumulations of Silurian limestone in the deeper western portion of the basin form the basin's oil and gas reservoirs. Silurian age sediments are not very thick in the basin.

The Devonian was a time of erosion and non-deposition throughout the basin and is represented only by thin cherts and shales. Evidence of the Acadian Orogeny is preserved as Grenville-age gravels in damictite and by the stratigraphic position of the Hillabee greenstone volcanic arc complex on the eastern margin of the basin.

\section{MISSISSIPPIAN}

The Black Warrior Basin included a quiet, tectonically stable platform in the northeast that supported a flourishing carbonate shelf facies in the early Mississippian. The basin sloped rapidly toward the south and southwest where deep-water clays accumulated. At the base of the Mississippian sequence, the Fort Payne chert is a distinctive lithologic marker and provides a common datum below the carbonates of northeastern Alabama on the platform edge and the clastic facies lying on the southwest (Hewitt 1984). On the margin of the Warrior platform, the Fort Payne chert is overlain by the Mississippian Tuscumbia limestone, Monteagle limestone and the Pride Mountain Formation. 


\section{Tuscumbia Formation}

The Tuscumbia Formation thins toward the southwest and pinches out entirely in the Appalachian synclines to the southeast as the result either of a facies change from shallow water carbonates to deeper water clastics or as a gradation to the upper Fort Payne. The Tuscumbia is overlain by the Monteagle Limestone in northeastern Alabama and by either of two clastic units, the Floyd Shale or Pride Mountain Formation elsewhere (Hewitt 1984).

\section{Monteagle Limestone}

The Monteagle Limestone contains scattered interbeds of dolomitic limestone that increase in number to the northeast. A basal layer of blocky chert in northern Alabama appears to be an extension of the Lost River chert in Tennessee (Ferguson and Stearns 1967). The Monteagle grades from the limestone to interfinger with a time-equivalent shale (the Pride Mountain Formation) or the Hartselle Sandstone in the southwest off the Warrior Platform. To the southeast, carbonates are absent in the Appalachian folds, and shale is found in this interval (Hewitt 1984).

\section{Pride Mountain Formation}

The Pride Mountain Formation is the leading edge of the thick clastic wedge that prograded from the southwest and forms a major tongue of the Floyd Shale. Beyond the 
southwestern limit of the Hartselle Sandstone, the Pride Mountain cannot be distinguished from the Floyd Shale. It is the most lithologically variable Carboniferous unit in the Warrior Basin and contains diverse fauna. In the northwest, the shale of the Pride Mountain Formation grades into limestone; to the southwest, the formation contains one to three sandstone units each of which may include interbedded limestones locally. Four sand units exist and are widespread within the Floyd Shale (Hewitt et al.1984). Evidence supports their formation as offshore shallow marine bars and/or intermittent barrier islands developed upon high spots on the East Warrior Platform. Though part of the Pride Mountain and its time equivalent (Floyd Shale) may be brackish lagoon deposits, much of the sequence is marine or back-barrier marine (Thomas 1972).

The Hartselle Sandstone, the largest of the four sandy units, is typically composed of well-sorted, light-grey to grey-brown fine quartz sand. The unit is of a variable thickness with three thickness maxima in southeastward-trending belts spaced about 25 miles apart. Both marine and plant fossil fragments have been found in the Hartselle (McCalley 1886). The Hartselle Sandstone is thought to represent a barrier island complex whose edge paralleled the edge of the east Warrior Platform (Thomas and Mack 1982). To the northeast, it prograded over the carbonate bank to interfinger with limestone and pinched out entirely in the back-barrier marine and/or lagoonal clays of the Floyd Shale or Pride Mountain deposits (Hewitt 1984). 


\section{PENNSYLVANIAN}

\section{Structure}

The regional dip of the Black Warrior Basin strata is locally disrupted by several broad, generally symmetrical, doubly plunging folds along the southeastern margin of the basin. The most prominent of these folds include the Coalburg syncline, the Sequatchie anticline and the Arkadelphia syncline. The axes of these folds are parallel to those of the Appalachian fold and thrust belt thus suggesting an affinity with Allegheny orogeny formation (Thompson and Telle 1987). The net closure of the folds, north of Birmingham, Alabama, is several hundred feet, but the folds becure unrecognizable southwestward in the vicinity of Tuscaloosa.

Structural mapping of the Black Warrior Basin indicates a relatively high fault density adjacent to the Appalachian structural front. The high fault density identification, however, may be the result of data availability. This is because the most intensive mining and exploration has been conducted in this part of the basin and the structure of the basin is therefore better defined here (Thompson and Telle 1987). In reality, normal faulting appears widespread throughout the basin.

Normal faults are almost exclusively gravity faults striking generally to the northwest in the basin and vary considerably in displacement and length. These different sizes of faults 
collectively form horst-and-graben structures and often exhibit an en echelon pattern. The fault displacement ranges from several feet to over 350 feet in the exposed portion of the basin and may exceed 1,000 feet beneath the coastal plain cover. Strike lengths range from less than a hundred feet to a few miles. Faults in the Brookwood and Oak Grove degasification fields generally strike between N30W and N40W and average N34W. This preferred orientation probably represents tensional fracturing associated with the Allegheny orogeny (Ward et al. 1984). Measured dips of fault planes at the surface and in underground mines are usually about 70 degrees but may vary across the basin. Where displacement is significant, structural disruption along the fault plane usually extends only several feet.

Fault zones (faults expressed as a zone of numerous smaller faults) often contain several feet of gouge that typically resembles contorted underclay and sometimes inhibits fault zone recognition, especially in core samples. Secondary sulfide, sulfate and carbonate mineralization may be associated with the fault zones (Thompson and Telle 1987).

Other faults generally concentrated in the western part of the basin and not conforming to the general trends include reverse and thrust faults and those striking other directions other than northwest. This type of faulting possibly reflects regional structural disturbances related to the uplift of the Nashville Dome and subsidence of the Mississippi Embayment. 
Persistent joint trends of locally variable strike have been identified in the Warrior Coal Basin. Two dominant trends apparently related to Alleghenian compression strike approximately N50E and N58W (Thompson and Telle 1987). Ward et al. (1984) attributed these trends to release and shear jointing, respectively. The northeast-trending set also may represent extensional jointing formed in response to Ouachitan compression and reactivation during Alleghenian compression (Thompson and Telle 1987).

Coal cleating appears more uniform throughout the basin. Dominant face and butt cleat orientations are approximately $\mathrm{N} 60 \mathrm{E}$ and $\mathrm{N} 28 \mathrm{~W}$, respectively. These cleating orientations are related to Ouachitan compression which was occurring during coalification (Ward et al. 1984).

The most prominent feature of the Warrior coal field within the Black Warrior Basin is the general south-southwestward dip of the basin strata. Near the Appalachian structural front, the basin strata have been broadly folded into several northeast to southwest trending anticlinoria and synclinoria or regional fold structures composed of lesser folds (Thompson and Telle 1987). The Birmingham anticlinorium separates the Black Warrior coal field from the Cahaba synclinorium and Cahaba coal field. Another anticlinorium separates the Cahaba field from the Coosa synclinorium and Coosa coal field. Figure 3 shows the location of these coal fields. 


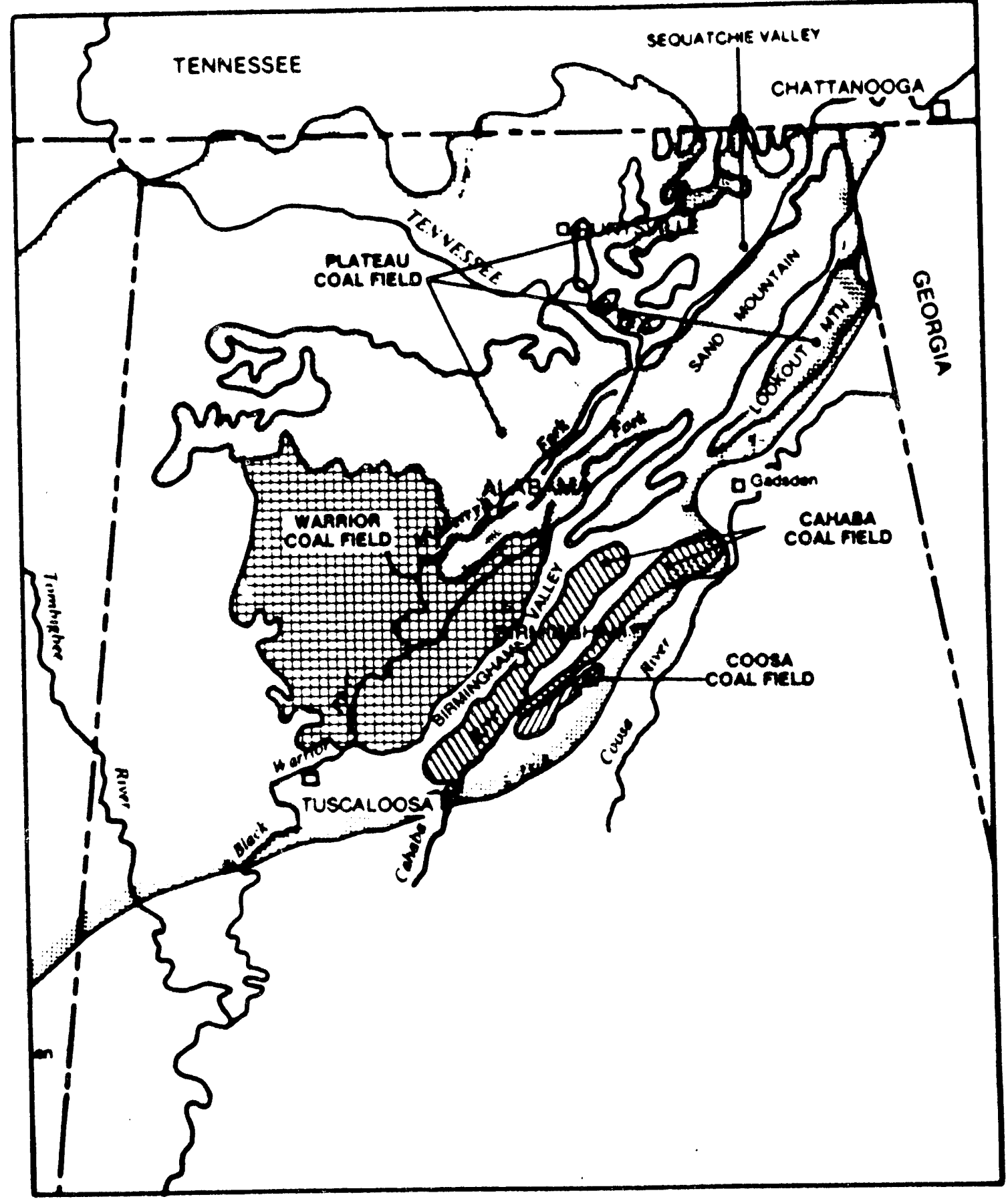

Figure 3. Coal Fields of the Eastern Warrior Basin (after Hewitt 1984). 
The base of the Pottsville Formation approaches an elevation of $1,000 \mathrm{ft}$. below sea level near its up dip limit in northern Alabama and, within a distance of 100 miles, descends to at least 5, 500 feet below sea level in west-central Alabama.

\section{Stratigraphy of Coal-Bearing Rocks (Pottsville)}

The coal-' 'earing rocks of the Warrior Coal Basin consist largely of a sequence of siltstone, sandstone and shale with minor conglomerate, coal, underclay and limestone. The coal-bearing rock sequence are assigned to the Pottsville Formation and belong to the Pocahontas and New River stages of the Morrow Series of the Pennsylvanian (Thompson and Telle 1987). Butts (1926) placed the division between these stages at about the middle of the Pennsylvanian section at the Black Creek seam. The Black Creek seam marks the northern extent of the Warrior Coal Basin. The New River stage contains the Warrior coal basin's important commercial coals (those in and above the Black Creek Coal Group). It is within this section that coalbed methane development has occurred to date. General correlations from the Warrior coal field, the largest and most productive of the Black Warrior Basin fields, to the Cahaba and Coosa fields are shown in Figure 4.

The average net thickness of the Pennsylvanian strata in the Warrior Coal Basin south and west of Tuscaloosa, Alabama is over 4,500 feet. Thinning of the strata occurs northward primarily because of a post-Pennsylvanian erosional unconformity (Thompson and Telle 1987). The section dips less than one degree per mile southward beneath the coastal 


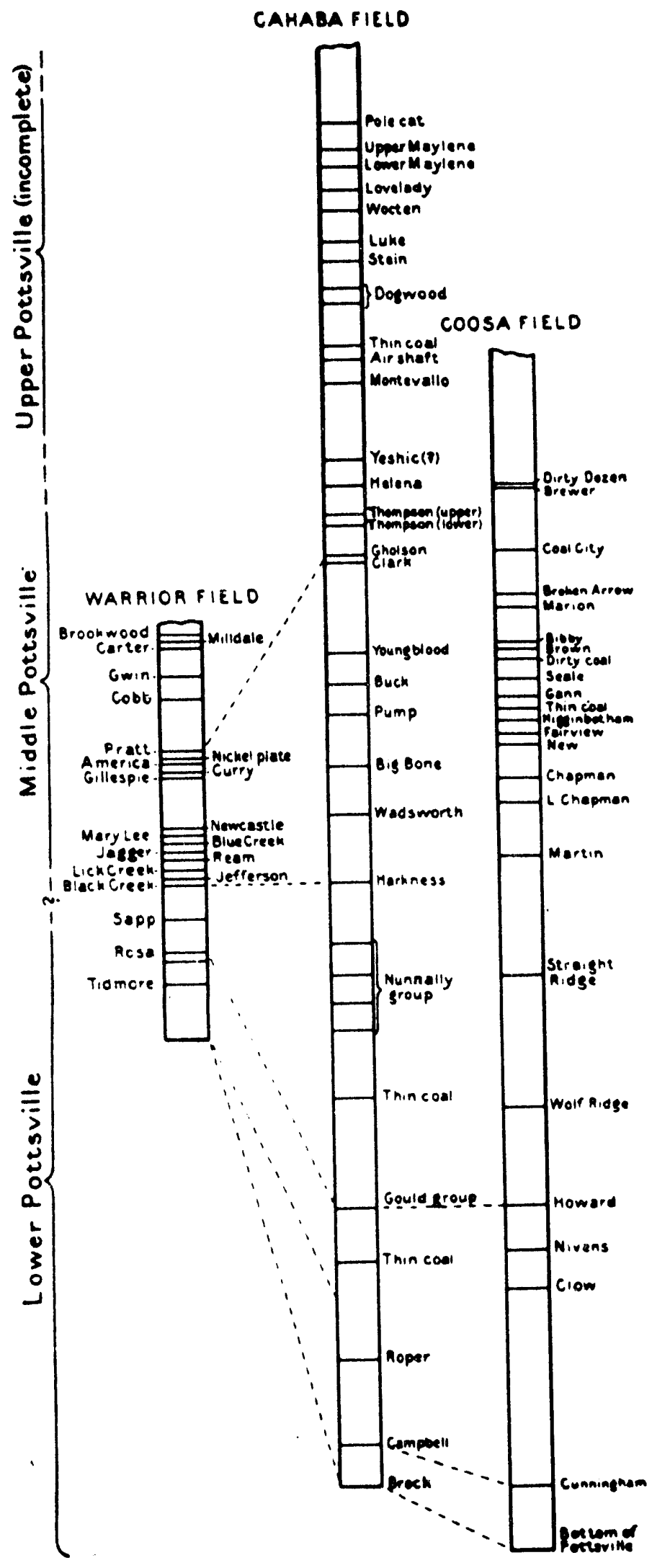

Figure 4. Correlation of Coal Seams between the Major Warrior Basin Coal Fields (after Butts 1926). 
plain cover southwest of Tuscaloosa. Because the top of the Pennsylvanian section also dips southward, its net thickness does not increase significantly in that direction.

\section{COAL AND COALBED METHANE - OCCURRENCE AND CHARACTERISTICS}

Pottsville Formation coal-bearing strata probably were deposited in an ancient deltaic environment (Ferm et al. 1967). Systematic characterization by cores and electric logs indicates that the coals and associated strata accumulated in a variety of settings in two depositional systems. Coals in the lower Pottsville Formation formed in swamps and lagoons southwest (landward) of a nearshore barrier island chain. Coals in the upper Pottsville formed in a complex system of distributary channels, levees, interdistributary swamps and bays, bay margins and fills, overbank swales and crevasse splays (Thomas and Womack 1983; Thomas and Hines 1986). Lateral and vertical variations in lithologic distribution suggest that the deltaic depositional system shifted dynamically in response to broad climatic, eustatic and sedimentological changes through the time of coal deposition (Thompson and Telle 1987).

\section{COAL OCCURRENCE}

The Pottsville Formation coal group occurs in formal stratigraphic groups distributed throughout several tens of feet of section and separated by several hundred feet of barren strata (McCalley 1900). Though individual coal seams are seldom correlatable over a large 
area, coal groups are generally traceable in the basin. Groups of vertical agglomeration of coal seams separated by barren strata probably represent temporary reductions in clastic sedimentation which allowed extensive peat swamps to form and persist through time (Thompson and Telle 1987). These reductions in sediment input may have resulted from deceleration of basin subsidence, decrease in uplift of the acjacent highlands, regional drainage adjustment in response to eustatic changes, or combinations of these factors. (Thompson and Telle 1987). The fact that many coal groups are overlain by marine sediments indicate brief marine incursions following the peat-forming episodes and preceding subsequent influxes of terrestrial clastics. Faulting reportedly controlled the occurrence and thickness of Pottsville Formation coal in the Pratt cycle in the northern Black Warrior Basin (Weisenfluh and Ferm 1984) and in the Mary Lee cycle in the Oak Grove field (Epsman et al. 1988; Pashin et al. 1989). Based on these studies, the thickest coals occur in upthrown fault blocks but split and thin onto adjacent downthrown blocks.

Eight coal groups in the Warrior Coal Basin are presently established in the literature (Figure 5). These groups are listed in descending order as the (1) Brookwood, (2) Utley, (3) Gwin, (4) Cobb, (5) Pratt, (6) Mary Lee, (7) Black Creek and (8) J interval. A ninth group, the Sypsey group, described by Thompson and Herz (1982) lies stratigraphically above the Brookwood and defines the youngest known coal horizon in the basin. These coal horizons are unconformably overlain by coastal plain deposits, hence no outcrops are known in this group. However, limited available core and proprietary data indicate that this coal 


\section{Coal Beds}

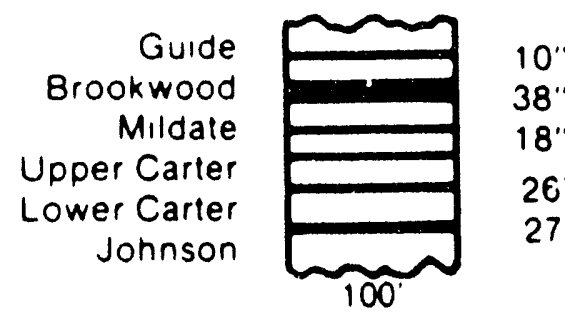

Unamed

Thompson Mil

Cobb Upper Cobb Lower

Thomas

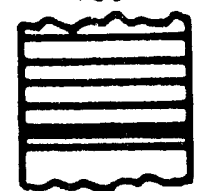

100

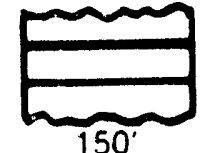

$23^{\prime \prime}$

16

$24^{\prime \prime}$

24 "

BROOKWOOD

GROUP

$125^{\circ}$

UTLEY GROUP $100^{\circ}$

GWIN GROUP $45^{\circ}$

COBB GROUP 44 "

$17 "$

$17^{\prime \prime}$

14 "

200

Prall

Fire Clay

American

Curry

Gillespy

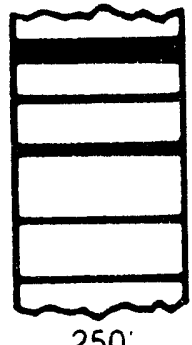

$36^{\prime \prime}$

16 "

$30^{\prime \prime}$

10 "

13

$250^{\circ}$

New Castle

Mary Lee

Blue Creek Jagger

Ream

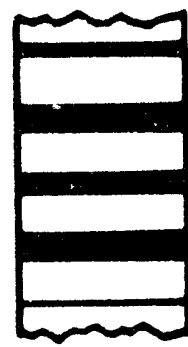

27

36 "

28 "

$27^{\prime \prime}$

$9 "$

$100^{\circ}$

L.ick Creek Jefferson Murphy

Black Creek

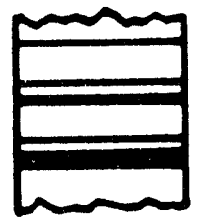

$9 "$

$27^{\prime \prime}$

3"

$27^{\prime \prime}$

$250^{\circ}$

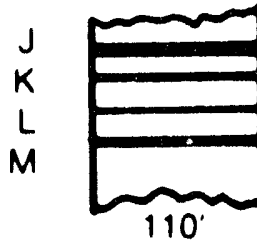

$30 "$

$12^{\prime \prime}$

$9 "$
PRATT GROUP $150^{\circ}$

MARY LEE GROUP $150^{\circ}$

BLACK CREEK GROUP $100^{\circ}$

$J$ GROUP $1500^{\prime}-2000^{\prime}$

Figure 5. Warrior Coal Basin Coalbeds (after Hewitt 1984). 
group is aerially extensive west and south of Tuscaloosa (Thompson and Telle 1987). Most of this new coal group areal extent lies within the Sypsey River drainage basin southwest of Tuscaloosa (Thompson and Telle 1987).

All coalbed methane development are primarily confined, in decreasing order of importance, to Mary Lee, Black Creek, Pratt, Cobb, and Gwin coal groups. General descriptions of the eight older coal group are given below.

Brookwood Coal Group: The Brookwood group lies 200 to 300 feet above the Ut':y coal group and consists of five seams which, in ascending order, are the Clements, Johnson or (Carter), Mildale, Brookwood, and Guide seams. The lowest, the Clements seam, is thin or absent in many places but has been mined locally where it reaches a thickness of 30 to 36 inches. Some 60 feet above is the Johnson seam. This bed has an average of 25 inches of thickness and has been mined only locally. The Milldale is found 30 feet or more above the Johnson bed and rarely exceed 30 inches in thickness. It merges with the overlying Brookwood coalbed to form a seam 70 to 80 inches thick. The thickest, most extensive and persistent bed in this group is the Brookwood seam. It lies one to 40 feet above the Milldale seam, averages 40 to 50 inches in thickness and has been mined extensively for coking coal. The thin Guide coalbed lies 30 feet above the Brookwood and has been removed by erosion in many places (Hewitt 1984). Because of the thickness and depths of the seams, this coal group does not have sufficient capacity to retain significant quantities of gas (Thompson and Telle 1987). 
Utley Coal Group: This group of two to six coalbeds ranges over a vertical interval of 20 to 150 feet and lies from 250 to 320 feet above the Gwin coal group. A coalbed that correlates with the Utley in southern Jefferson County is more than 30 inches thick. This seam is medium to volatile bituminous in rank with low sulfur and moderate ash contents. Like the Brookwood coal seam, this group does not have sufficient capacity to retain significant quantities of gas.

Gwin Coal Group: The Gwin coal group lies 120 to 160 feet above the Cobb coal group and consists of Gwin and Thompson Mill seams. The group lies in depth in excess of 500 feet in areas of coalbed degasification fields. The Gwin coalbed is approximately 35 feet above the Thompson Mille bed and ranges from 1.4 to several feet in thickness (Hewitt 1984; Thompson and Telle 1987). Because the seam is persistent but erratic, attempts in the past to develop it were limited. However, very recently, coalbed degasification development bigan in the lower Gwin group (Hewitt 1984; GRI Quarterly Review April 1993).

Cobb Coal Group: The Cobb coal group consists of three coalbeds. These are in ascending order, the Thomas, the lower Cobb and the upper Cobb (McCalley 1900). The coalbeds lie from 210 to 330 feet above the Pratt group over a stratigraphic interval of 50 feet. McCalley (1900) reported a total thickness between 3 and 4 feet for the coal group, but Culbertson (1964) estimated that the group thickness rarely exceed 2 feet. Although the Cobb group locally exhibits two prominent benches, Thompson and Telle (1987) consider 
the groups as only one coal seam with a thickness between one to three feet thick which serves as a reliable marker horizon for stratigraphic correlation.

Pratt Coal Group: The Pratt Coal Group consists of five seams in ascending order; Gillepsie, Curry, American, Nickel Plate (or Fire Clay) and Pratt. The Pratt group lies between 400 to 650 feet above the Mary Lee group. The Gillepsie seam lies approximately 50 feet below the Curry which in turn lies approximately 100 feet below American. The upper three seams are usually within a 50-foot interval. The Pratt seam is the principal and most persistent of the seams (Hewitt 1984; Thompson and Telle 1987). Within the Coalburg syncline, the Pratt seam ranges from 30 to 75 inches in thickness. The Pratt and the American seams have been extensively deep-mined in the eastern part of the basin. The Pratt seam coal contains relatively little ash and sulfur and is an excellent coking coal (Hewitt 1984). Though Curry and Gillepsie are widespread, they are generally less than one foot in thickness and serve only as stratigraphic markers. The Nickel Plate seam rarely exceeds two feet in thickness and is deep-mined where it merges with the Pratt seam to form the Corona seam (Thompson and Telle 1987).

Mary Lee Coal Group: The Mary Lee coal group, containing the largest reserves of the Black Warrior Basin coal fields, consists of five seams in ascending order; the Ream, Jagger, Blue Creek, Mary Lee/Blue Creek, and New Castle coal seams (Hewitt 1984; and Telle 1987). The New Castle seam is a thin, discontinuous bed found 15 to 65 feet above Mary Lee. This seam may form up to three benches and often is mistaken for the Mary Lee 
bed (Hewitt 1984). The thickest seam in the group is the Mary Lee or Mary Lee/Blue Creek seam. The Mary Lee is up to six feet th. $\therefore$ in the northern part of the basin and from six to eight feet thick in the southwest. The Blue Creek coal is mined in the Blue Creek Basin in southern Jefferson County and can be traced northward through logs and boreholes until it intertongues with the top bench of the Mary Lee coalbed (Murrie et al. 1976). Mary Lee and Mary Lee/Blue Creek have also been extensively deep mined in the east central part of the basin. Mary Lee is usually reported as two benches that merge together to form one seam in the northern part of the field but split into as many as five benches locally (Murrie et al. 1976). Because of correlation difficulties and a change in coal rank across the basin, the Blue Creek seam is a low-to-medium volatile with generally low sulfur and high ash contents (Hewitt 1984). The most significant coalbed methane development in the basin also has occurred in the combination of the Mary Lee/Blue Creek seams.

Black Creek Coal Groud: The Black Creek coal group is the lowest consistently workable horizon in the Black Warrior coal field and underlies a large area in Jefferson, Walker, Cullman and Blount Counties, Alabama. The Black Creek group ranges over a stratigraphic interval of 50 to 150 feet and is composed of three beds which are, in ascending order, the Black Creek, Jefferson and Lick Creek coalbeds (McCalley 1900). Because the Lick seam is thin and contains many partings, the Black Creek coal group resources are wholly confined to the Black Creek and Jefferson coal seams. The Jefferson coalbed ranges in average thickness from 10 to 30 inches with a maximum thickness up to 
60 inches. This coal seam is a high volatile, an A rank, bituminous coal with low to moderate ash and variable sulfur contents. The Black Creek seam averages 20 to 26 inches in thickness but thins and grades into carbonaceous shale to the west of northwest Walker, southern Winston and southeastern Marion counties. This coal seam produces a high quality coal having the lowest ash and sulfur contents of any of the major beds in the Warrior coal field and it is a high volatile, bituminous A rank coal (Hewitt 1984). Examples of average analyses of coals in the Warrior coal field may be found Table 1.

\section{COALBED METHANE OCCURRENCE}

\section{Warrior Coal Field}

Coalbeds in the Warrior field have a century-old reputation for being rich in methane content. Methane was reported in about $20 \%$ of the producing coal mines (Butts 1926). Most studies on methane in the basin have been directed specifically toward problems of emissions during underground mining and toward determining the feasibility of degasification prior to mining.

Information currently available about methane potential in the Black Warrior Basin is summarized as follows (Hewitt 1984): 


\begin{tabular}{|c|c|c|c|c|c|c|c|c|c|c|c|c|}
\hline \multirow[b]{2}{*}{ Coal Bed } & \multicolumn{4}{|c|}{$\begin{array}{l}\text { Proxımate Analysis } \\
(\%)\end{array}$} & \multicolumn{4}{|c|}{$\begin{array}{c}\text { Ultimate Analysis } \\
(\%)\end{array}$} & \multirow[b]{2}{*}{$\begin{array}{c}\text { Sulfur } \\
(\%)\end{array}$} & \multirow[b]{2}{*}{ Btu } & \multirow{2}{*}{$\begin{array}{c}\text { Ash } \\
\text { Softening } \\
\text { Temperature } \\
\left({ }^{\circ} \mathrm{F}\right) \\
\end{array}$} & \multirow{2}{*}{$\begin{array}{c}\text { Number } \\
\text { of } \\
\text { Analyses } \\
\text { Averaged }\end{array}$} \\
\hline & Moisture & $\begin{array}{l}\text { Volatile } \\
\text { Matter } \\
\end{array}$ & $\begin{array}{l}\text { Fixed } \\
\text { Fixed } \\
\text { Carbon } \\
\end{array}$ & Ash & Hydrogen & Carbon & Nitrogen & Oxygen & & & & \\
\hline \multicolumn{13}{|c|}{ Jefferson County } \\
\hline \begin{tabular}{|l|} 
Black Creek \\
Jefferson \\
Blue Creek \\
Mary Lee \\
Newcastle \\
American \\
Nicke! Plate \\
Pratt \\
Utley' \\
\end{tabular} & $\begin{array}{l}3.0 \\
2.3 \\
3.1 \\
2.4 \\
3.0 \\
3.1 \\
2.3 \\
2.5 \\
1.2 \\
\end{array}$ & $\begin{array}{l}31.6 \\
31.9 \\
23.4 \\
27.2 \\
30.5 \\
30.5 \\
29.2 \\
29.4 \\
24.5 \\
\end{array}$ & $\begin{array}{l}62.1 \\
58.5 \\
63.6 \\
58.1 \\
52.7 \\
59.6 \\
59.2 \\
62.6 \\
65.3 \\
\end{array}$ & \begin{tabular}{r|}
3.3 \\
7.3 \\
9.9 \\
12.3 \\
13.8 \\
6.6 \\
9.2 \\
6.4 \\
9.0 \\
\end{tabular} & $\begin{array}{l}5.3 \\
5.1 \\
4.9 \\
4.8 \\
5.0 \\
5.2 \\
4.9 \\
5.1 \\
4.7 \\
\end{array}$ & $\begin{array}{l}81.4 \\
76.7 \\
76.7 \\
73.3 \\
69.9 \\
781 \\
75.5 \\
79.4 \\
77.4 \\
\end{array}$ & $\begin{array}{l}1.8 \\
1.6 \\
1.5 \\
1.6 \\
1.6 \\
1.5 \\
1.4 \\
1.6 \\
1.4 \\
\end{array}$ & $\begin{array}{l}7.5 \\
6.2 \\
6.2 \\
6.4 \\
7.7 \\
7.2 \\
6.7 \\
5.9 \\
6.2 \\
\end{array}$ & $\begin{array}{r}0.7 \\
3.1 \\
.8 \\
1.1 \\
2.0 \\
1.2 \\
2.2 \\
1.4 \\
1.3 \\
\end{array}$ & $\begin{array}{l}14.310 \\
13.780 \\
13.530 \\
12.840 \\
12.590 \\
13.650 \\
13.540 \\
14.250 \\
13.360 \\
\end{array}$ & $\begin{array}{l}2,500 \\
2,300 \\
2.900 \\
2.680 \\
2.450 \\
2.480 \\
2,420 \\
2,460 \\
2,690 \\
\end{array}$ & $\begin{array}{r}4 \\
3 \\
1 \\
10 \\
1 \\
2 \\
2 \\
10 \\
2 \\
\end{array}$ \\
\hline \multicolumn{13}{|c|}{ Marion County } \\
\hline Jefferson & 5.2 & 37.3 & 54.1 & 3.3 & 5.6 & 76.0 & 16 & 12.0 & 1.3 & 13.600 & 2,250 & 2 \\
\hline \multicolumn{13}{|c|}{ Tuscaloosa County } \\
\hline \begin{tabular}{|l|} 
Jefterson \\
Blue Creek \\
Mary Lee \\
Pratt \\
Carter \\
Milldale \\
Brookwood \\
\end{tabular} & $\begin{array}{l}1.4 \\
1.4 \\
1.0 \\
1.4 \\
3.2 \\
3.8 \\
3.5 \\
\end{array}$ & $\begin{array}{l}32.6 \\
30.5 \\
32.5 \\
36.6 \\
31.1 \\
31.4 \\
28.7 \\
\end{array}$ & $\begin{array}{l}61.4 \\
52.2 \\
51.0 \\
53.5 \\
59.9 \\
59.9 \\
58.0 \\
\end{array}$ & $\begin{array}{r}4.6 \\
15.9 \\
15.5 \\
8.3 \\
5.8 \\
4.9 \\
9.7 \\
\end{array}$ & $\begin{array}{l}- \\
- \\
- \\
\overline{5.4} \\
5.1\end{array}$ & $\begin{array}{c}- \\
- \\
- \\
\overline{7} \\
78.3 \\
74.5\end{array}$ & $\begin{array}{l}\overline{-} \\
- \\
\overline{-} \\
\overline{1.4} \\
1.5\end{array}$ & $\begin{array}{l}- \\
- \\
- \\
- \\
\overline{8.6} \\
8.1\end{array}$ & $\begin{array}{r}1.4 \\
2.3 \\
1.6 \\
2.0 \\
.9 \\
1.4 \\
1.0 \\
\end{array}$ & $\begin{array}{l}14,310 \\
12.400 \\
12.580 \\
13.650 \\
14.020 \\
14,030 \\
13.270 \\
\end{array}$ & $\begin{array}{c}- \\
- \\
\overline{-} \\
2.800 \\
2.320 \\
2.850 \\
\end{array}$ & $\begin{array}{l}1 \\
1 \\
1 \\
1 \\
1 \\
3 \\
2 \\
\end{array}$ \\
\hline \multicolumn{13}{|c|}{ Walker County } \\
\hline \begin{tabular}{|l|} 
Black Creek \\
Jefferson \\
Jagger \\
Mary Lee \\
American \\
Pratt \\
Corona
\end{tabular} & $\begin{array}{l}3.0 \\
4.1 \\
3.8 \\
3.3 \\
2.3 \\
2.0 \\
2.4\end{array}$ & $\begin{array}{l}36.3 \\
36.7 \\
33.1 \\
30.5 \\
32.5 \\
34.8 \\
38.9\end{array}$ & $\begin{array}{l}58.1 \\
55.0 \\
50.4 \\
53.5 \\
52.9 \\
54.9 \\
49.0\end{array}$ & \begin{tabular}{r|}
2.5 \\
4.2 \\
12.5 \\
12.7 \\
12.3 \\
8.3 \\
9.7
\end{tabular} & $\begin{array}{l}5.6 \\
5.5 \\
5.1 \\
5.0 \\
5.0 \\
5.3 \\
5.4\end{array}$ & $\begin{array}{l}80.4 \\
76.3 \\
67.9 \\
70.4 \\
71.5 \\
754 \\
713\end{array}$ & $\begin{array}{l}1.8 \\
1.7 \\
1.6 \\
1.6 \\
1.5 \\
1.7 \\
1.7\end{array}$ & $\begin{array}{r}8.8 \\
10.8 \\
11.4 \\
9.7 \\
8.0 \\
7.2 \\
9.6\end{array}$ & $\begin{array}{r}0.9 \\
1.5 \\
1.2 \\
.7 \\
1.6 \\
2.1 \\
2.3\end{array}$ & $\begin{array}{l}14,280 \\
13.590 \\
12.210 \\
12.280 \\
12.530 \\
13.420 \\
12,880\end{array}$ & $\begin{array}{c}2.460 \\
- \\
2.730 \\
2.740 \\
2.720 \\
2.360 \\
2.400\end{array}$ & $\begin{array}{r}5 \\
1 \\
2 \\
12 \\
2 \\
3 \\
1\end{array}$ \\
\hline
\end{tabular}

'This coal bed is called Clements. where sampled.

Table 1. Average Analyses of Coal in the Warrior Coal Field (after Culbertson 1964). 
1. Multi-well fields attain better production than single wells and generally improve as more wells are placed into production. Coalbed permeability appears to actually increase over time.

2. A joint DOE/U.S. Steel project installed 28 wells which were stimulated with different hydraulic fracturing techniques. Conventional hydraulic stimulation using sand proppant was more successful in enhancing methane production than any stimulation without proppant.

3. There is typically a long de-watering period prior to significant production from the Mary Lee seam. This suggests a complex two-phase relationship between saturation and permeability that changes with time.

4. Horizontal drilling by the U.S. Bureau of Mines in the Mary Lee showed total methane recovered from one hole was as much as $\mathbf{4 0}$ million cubic feet over 10 months and effectively reduced emissions at the mine working face.

5. DOE/USGS investigated the feasibility of methane recovery on a series of federal coal leases. The results are presented in Table 2 . 


\begin{tabular}{|c|c|c|c|c|c|c|c|c|c|c|c|c|}
\hline \multirow[b]{2}{*}{ Location } & \multirow{2}{*}{$\begin{array}{l}\text { USGS } \\
\text { Woyl } \\
\text { Number }\end{array}$} & \multirow{2}{*}{$\begin{array}{l}\text { MPCP } \\
\text { Whin } \\
\text { Neme }\end{array}$} & \multirow{2}{*}{$\begin{array}{l}\text { Dere } \\
\text { Sempled }\end{array}$} & \multirow[b]{2}{*}{ Group/seam } & \multirow{2}{*}{$\begin{array}{l}\text { Depth } \\
\text { (in) }\end{array}$} & \multirow{2}{*}{$\begin{array}{l}\text { Thucknoses } \\
\text { (ii) }\end{array}$} & \multirow{2}{*}{$\begin{array}{l}\text { Semple } \\
\text { Worght } \\
\text { (gm) }\end{array}$} & \multirow{2}{*}{$\begin{array}{l}\operatorname{Los} \\
\operatorname{Ges} \\
(\mathrm{cc})\end{array}$} & \multirow{2}{*}{$\begin{array}{l}\text { Desorbed } \\
\text { Ges } \\
\text { (cc) }\end{array}$} & \multirow{2}{*}{$\begin{array}{l}\text { Resudual } \\
\text { Gas } \\
\text { (cc) }\end{array}$} & \multicolumn{2}{|c|}{ Gas Content } \\
\hline & & & & & & & & & & & $(\mathrm{cc} / \mathrm{gm})$ & (cinon) \\
\hline \multirow{2}{*}{$\begin{array}{l}\text { Grace, Grimsley } 35.15 \text { il } \\
\text { SW/4-SE/4 Sec 34, T14S. R1 iw } \\
\text { Fayette Co. AL }\end{array}$} & N/A & CAA & $7 / 12 / 79$ & Blue Creek & 593 & 1.0 & 1.789 & $\begin{array}{l}7156 \\
3942\end{array}$ & $\begin{array}{l}3.757 \\
1.511\end{array}$ & $\begin{array}{l}358 \\
197\end{array}$ & $\begin{array}{l}2.7 \\
32\end{array}$ & $\begin{array}{r}86 \\
102\end{array}$ \\
\hline & $N / A$ & CAA & $\begin{array}{l}7 / 13 / 79 \\
7 / 16 / 79 \\
7 / 18 / 79\end{array}$ & $\begin{array}{l}\text { Unnamed H } \\
\text { Rosa } \\
\text { Tidmore B }\end{array}$ & $\begin{array}{l}1,102 \\
1.675 \\
1.879\end{array}$ & $\begin{array}{l}2.0 \\
2.5 \\
3.0\end{array}$ & $\begin{array}{r}657 \\
1.198 \\
1,113\end{array}$ & $\begin{array}{l}119.8 \\
1113\end{array}$ & $\begin{array}{r}240 \\
1.336\end{array}$ & $\begin{array}{r}240 \\
1.002\end{array}$ & $\begin{array}{l}0.5 \\
2.2\end{array}$ & $\begin{array}{l}16 \\
70\end{array}$ \\
\hline $\begin{array}{l}\text { SW/4 Sec. 19. T14S, R9W } \\
\text { Walker Co.. AL }\end{array}$ & $\begin{array}{l}57 \\
\text { KRCRA.2 }\end{array}$ & $\mathrm{CAB}$ & $\begin{array}{l}10 / 16 / 79 \\
10 / 21 / 79\end{array}$ & Mary Lee/Mary Lee & 578 & 117 & \multicolumn{3}{|c|}{ No Samples Collected } & & & \\
\hline $\begin{array}{l}\text { SW/4.SW/4 Sec. 18. T18S. R9W } \\
\text { Tuscaloosa Co., AL }\end{array}$ & $\begin{array}{l}37 \\
\text { KACRA-2 }\end{array}$ & CAC & $2 / 5 / 81$ & Mary Lee/Blue Creek & 1,502 & 26 & 5665 & 0 & 6.875 & 385 & 128 & 410 \\
\hline $\begin{array}{l}\text { SE/4.SE/4 Sec 4. TI7S. R9W } \\
\text { Tuscaloosa Co. AL }\end{array}$ & $\begin{array}{l}49 \\
\text { KRCRA.2 }\end{array}$ & CAD & $2 / 20 / 81$ & Mary Lee/Blue Creok & 1,314 & 6.6 & 1.157 & 125 & 10.457 & 575 & 9.6 & 309 \\
\hline $\begin{array}{l}\text { SE/4.SE/4 SeC. } 35, T 17 S . \text { R10W } \\
\text { Tuscaloosa Co. AL }\end{array}$ & 1 & CAE & $5 / 5 / 81$ & $\begin{array}{l}\text { Mary Lea/New Castle } \\
\text { Mary Lea/Mary Leo }\end{array}$ & $\begin{array}{l}1.147 \\
1.171\end{array}$ & $\begin{array}{l}1.3 \\
3.6\end{array}$ & $\begin{array}{l}437 \\
570\end{array}$ & 915 & $\begin{array}{l}4.312 \\
5.444\end{array}$ & $\begin{array}{l}445 \\
300\end{array}$ & $\begin{array}{l}111 \\
103\end{array}$ & $\begin{array}{l}355 \\
329\end{array}$ \\
\hline $\begin{array}{l}\text { NW/4.SE/4 Sec } 28 \text { TI8S. R9W } \\
\text { Tuscaloosa Co., AL }\end{array}$ & $\begin{array}{l}5 \\
\text { KRCRA.2 }\end{array}$ & CAF & $\begin{array}{l}5 / 5 / 81 \\
5 / 5 / 81 \\
5 / 11 / 81\end{array}$ & $\begin{array}{l}\text { Mary Lee/Mary Lee } \\
\text { Mary Lee/Mary Lee } \\
\text { Black CreekJ Jefferson }\end{array}$ & $\begin{array}{l}1.588 \\
1.589 \\
1.871\end{array}$ & $\begin{array}{l}2.7 \\
27 \\
2.35\end{array}$ & $\begin{array}{l}384 \\
408 \\
609\end{array}$ & $\begin{array}{l}71.6 \\
42.4 \\
-7.03\end{array}$ & $\begin{array}{l}4.300 \\
5.185 \\
1.995\end{array}$ & $\begin{array}{l}235 \\
390 \\
\text { test not } \\
\text { pert }\end{array}$ & $\begin{array}{r}12.0 \\
13.8 \\
3.3^{*}\end{array}$ & $\begin{array}{l}384 \\
441 \\
105\end{array}$ \\
\hline $\begin{array}{l}\text { SW/4 NE/4 Sec 3. T17S. R10W } \\
\text { Tuscaloosa Co. AL }\end{array}$ & $\begin{array}{l}3 \\
\text { KRCRA.2 }\end{array}$ & CAG & $5 / 14 / 81$ & $\begin{array}{l}\text { Black Creck/Jefferson } \\
\text { Black Creak/Jefierson }\end{array}$ & $\begin{array}{l}1.487 \\
1.487\end{array}$ & $\begin{array}{l}3.83 \\
3.83\end{array}$ & $\begin{array}{l}278 \\
459\end{array}$ & $\begin{array}{r}-241 \\
278\end{array}$ & $\begin{array}{l}1.776 \\
2.877\end{array}$ & $\begin{array}{l}340 \\
410\end{array}$ & $\begin{array}{l}75 \\
7.2\end{array}$ & $\begin{array}{l}2408 \\
2311\end{array}$ \\
\hline $\begin{array}{l}\text { SE/4-NW/4 Sec 28. TIBS. R2W } \\
\text { Tuscaloosa Co., AL }\end{array}$ & 9 & $\mathrm{CAH}$ & $\begin{array}{l}2 / 5 / 83 \\
2 / 5 / 82 \\
2 / 8 / 82 \\
2 / 8 / 82 \\
2 / 11 / 81 \\
2 / 11 / 82 \\
2 / 11 / 82 \\
2 / 12 / 82 \\
2 / 12 / 82 \\
3 / 18 / 82 \\
3 / 18 / 82 \\
3 / 19 / 82 \\
3 / 19 / 82 \\
3 / 1 / 82 \\
3 / 1 / 82 \\
3 / 3 / 82 \\
3 / 3 / 82 \\
3 / 4 / 82 \\
3 / 5 / 82 \\
3 / 5 / 82 \\
3 / 5 / 82\end{array}$ & 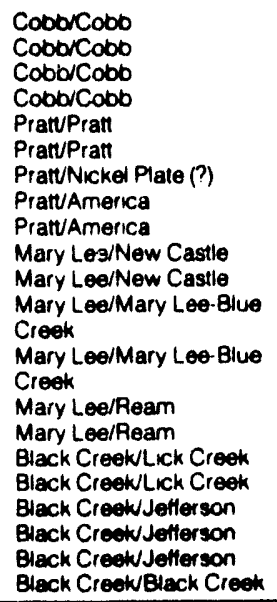 & $\begin{array}{l}769 \\
780 \\
793 \\
793 \\
1,061 \\
1,063 \\
1.074 \\
1.128 \\
1.129 \\
1.486 \\
1.486 \\
1.522 \\
1.522 \\
1.696 \\
1,715 \\
1.778 \\
1.797 \\
1,831 \\
1.850 \\
1.851 \\
1.879\end{array}$ & $\begin{array}{l}0.14 \\
10 \\
0.52 \\
0.52 \\
2.52 \\
2.52 \\
0.60 \\
142 \\
142 \\
3.1 \\
3.1 \\
5.4 \\
5.4 \\
036 \\
0.28 \\
0.43 \\
0.49 \\
0.40 \\
152 \\
152 \\
2.93\end{array}$ & $\begin{array}{r}137 \\
862 \\
232 \\
301 \\
1.494 \\
509 \\
776 \\
N / D \\
616 \\
1,377 \\
1,211 \\
1,487 \\
\\
1,375 \\
309 \\
187 \\
410 \\
470 \\
348 \\
678 \\
684 \\
1,659 \\
\end{array}$ & $\begin{array}{c}32.01 \\
33.5 \\
119 \\
161 \\
158.3 \\
1505 \\
49.3 \\
N / A \\
889 \\
555.0 \\
3413 \\
726.0 \\
\\
594.0 \\
32.5 \\
47.6 \\
181 \\
17.2 \\
356 \\
7099 \\
505.3 \\
7010\end{array}$ & $\begin{array}{r}1,115 \\
4,500 \\
1.838 \\
1,783 \\
12.643 \\
6,074 \\
9,568 \\
6,458 \\
8,375 \\
14,417 \\
12,513 \\
19,992 \\
19,132 \\
3,152 \\
2,664 \\
2,241 \\
2,653 \\
1,736 \\
10,386 \\
6,406 \\
25,158\end{array}$ & $\begin{array}{c}N / O \\
N / D \\
N / D \\
N / D \\
111 \\
N / D \\
N / D \\
N / D \\
N / D \\
144 \\
282 \\
71 \\
\\
352 \\
15 \\
N / D \\
41 \\
N / D \\
N / D \\
39 \\
123 \\
122\end{array}$ & $\begin{array}{r}8.4 \\
53 \\
8.0 \\
6.0 \\
8.6 \\
119 \\
124 \\
96 \\
137 \\
109 \\
10.6 \\
139 \\
143 \\
10.3 \\
143 \\
5.5 \\
5.7 \\
5.0 \\
164 \\
101 \\
15.6\end{array}$ & $\begin{array}{l}268 \\
168 \\
255 \\
191 \\
274 \\
391 \\
397 \\
307 \\
440 \\
348 \\
340 \\
446 \\
\\
459 \\
330 \\
467 \\
176 \\
182 \\
163 \\
524 \\
323 \\
499\end{array}$ \\
\hline
\end{tabular}

Table 2. Methane Data for Federal Coal Leases (after Hewitt 1984). 


\section{Cahaba Coal Field}

Studies conducted by Geologic Survey of Alabama show that deep coalbed methane resources may exist in the Cahaba tield.

In August 1992, the State Oil and Gas board of Alabama established the Little Buck Creek degasification field (Pottsville Formation coals) in the southwestern corner of Tuscaloosa County and adjoining Greene County. The field, situated between the Moundville and Taylor Creek fields, covers 17.5 square miles in T23 and T24N, R3E. The first well, the M Banks 20-07/\# owned by Meridian Oil has produced 1.101 MMCF of gas since June 1990 (GRI Quarterly Review February 1993).

\section{HYDROLOGY AND RESERVOIR CHARACTERISTICS}

During production of natural gas from coal seams, a significant volume of water is usually encountered. This water must be removed to reduce reservoir pressure, and hence allow desorption of methane from coal.

\section{Permeability/Porosity}

The upper Pottsville formation characteristically has low transmissivity, storage capacity and low water retention and generally low, non-uniform and irregular water yields 
to wells (Hinkle 1976). Hydrologic well tests in this formation indicate that permeability decreases with depth from approximately 100 millidarcies (md) at 100 feet to less than 10 md at 1,000 feet (Gas Research Institute Quarterly Review, July 1986). Data from a constant-rate injection test conducted in the Black Creek coal group Rock Creek site, near Birmingham, Alabama showed response that indicates a compound fracture consisting of (1) a circular horizontal component with a 45 -feet radius and radial permeability of $2.8 \mathrm{md}$; and (2) a 380-feet-long vertical component in a single coal seam with an effective thickness of 25 feet and vertical permeability of $21 \mathrm{md}$ (Hanson and Nielse 1986).

\section{Cleat and Joint Orientation}

Coalbed permeability is generally highest in the face cleat direction and varies greatly both locally among seams within a stratigraphic interval and regionally within a seam (Ayers 1990). Coal cleating appears more uniform throughout the basin. Dominant face and butt cleat orientations are apparently $\mathrm{N} 60 \mathrm{E}$ and $\mathrm{N} 28 \mathrm{~W}$ respectively (Thompson and Telle 1987). Murrie et al. (1976) measured surface and underground cleats and inclined fractures in the Mary Lee coal group in and around Western Jefferson, Southern Walker and Tuscaloosa counties, Alabama. They found, by constructing a single regional composite rose diagram, that fracture directions were quite varied and cleats showed numerous trends, especially in the western part of the study area. The study also indicated that the Mary Lee coal group has very pronounced face cleat peak at $\mathrm{N} 30 \mathrm{E}$ and a bimodal butt cleat peak at $\mathrm{N} 21 \mathrm{~W}$ and N36W. The authors suggested that the stress which produced the face cleat 
originated in the Ouachita orogeny to the southwest and were either extensional fractures oriented parallel to a maximum compressive stress or shear fractures. Because the maximum tensional stress in the Warrior basin is oriented perpendicular to the northeast-southwest axis of the depositional basin, the authors concluded that the face cleat was the result of shear.

Ward (1977) studied jointing in the Warrior coal field in Walker, Jefferson and Tuscaloosa counties and found two orthogonal fracture systems. One of the systems lies perpendicular to the Appalachian structural front and the other oriented parallel to the Appalachian front. Based on these findings, the author concluded that both fractures were extension-release fracture systems. The later joint set is prevalent in the western and southwestern parts of the coal field and formed earlier during the northeast-southwest stresses of the Ouachita Orogeny (Hewitt 1984). The former cleat system is prevalent only in the eastern and northeastern parts of the coal field and formed later by the northwestsoutheast maximum principal stresses of the Appalachian Orogeny.

\section{Water Quality}

Information from the Geological Survey of Alabama for total dissolved solids (TDS) of Mary Lee group produced waters reveals apparent structural control of groundwater movement. Total dissolved solids are lowest (TDS less than 1,000 milligrams per Liter or $\mathrm{mg} / \mathrm{L}$ ) along the southeastern boundary, marked with Blue Creek anticline, which has a 
maximum structural relief of approximately 2,000 feet. From this structural relief (a recharge zone), several tongues of low TDS water project basinward (northwest). Trends of known faults coinciding with these fresh-water tongues suggest structural influence on groundwater flow. Farther into the basin, Mary Lee group waters contain more than 3,000 $\mathrm{mg} / \mathrm{L}$ TDS (brackish water) and locally in excess of $10,000 \mathrm{mg} / \mathrm{L}$ (Ayers 1990).

The brackish water boundary through Peierson and Cedar Cove coal fields nearly coincides with the eastern limit of overlying unconsolidated Cretaceous strata. High TDS water may occur beneath this cover because of the Pottsville greater depth and the ability of Cretaceous strata to intercept recharge. This high TDS water raises the possibility of higher disposal costs for coalbed methane wells (Ayers 1990).

Fresh-water tongues parallel northwest-trending faults, and high TDS waters with chemical compositions similar to those of deep, lower Pottsville petroleum reservoirs are common in other faulted areas (Pashin et al. 1989). These observations indicate that lateral and vertical fluid movement occurs along the faults. The highly productive coalbed methane wells clustering along northeast-trending lineaments inferred to be associated with minor faults that commonly bound northwest-trending fresh-water tongues indicate that fractures strongly influence permeability in the Pottsville formation (Ayers 1990). 
COALBED METHANE DEVELOPMENT AND PRODUCTION IN THE BLACK WARRIOR DEGASIFICATION FIELDS

The major degasification coal fields of the Black Warrior Basin are Big Sandy Creek, Blue Creek, Boone Creek, Brookwood, Cedar Cove, Deerlick Creek, Gurnee, Holt, Little Buck Creek, Little Sandy Creek, Moundville, Oakgroove, Robinson's Bend, Scottsville, Taylor Creek, White Oak Creek and Wolf Creek.

\section{Coalbed Methane Production}

Coalbed methane development in the Black Warrior Basin of northwestern Alabama focussed primarily on the Mary Lee and Blue Creek coal seams (Mary Lee group). However, other coal seams, the shallower Pratt and Cobb group seams and the deep Black Creek group seams, have been targeted with several more recent wells drilled and completed in them. Very recently, development began in the shallow Gwin group (above the Cobb) and in the deep J interval coal seams. All these coal seams occur in the Pottsville formation (Lower Pennsylvanian) (GRI Quarterly Review April 1993).

Total coalbed methane production from 3,089 degasification wells in the basin's degassed fields was approximately 92 BCF in 1992 (GRI Quarterly Review April 1993; Petroleum Information Corporation 1992 e). This represents an increase of 35\% over the total production from 2,737 degasification wells in 1991 (GRI Quarterly Review April 1993). 
Companies actively involved in coalbed methane development and production are Energen/Chevron USA Inc./TECO Coalbed Methane Inc. joint venture, Taurus Exploration Inc., a subsidiary of Energen Corporation and Black Warrior Methane Corporation. Other operators include River Gas Corporation, MetFuel Inc., McKenzie Methane Corporation, Magnolia Methane Corporation and Torch Operating Company.

\section{Coalbed Methane Produced Water Discharge Regulations in Alabama}

Prior to 1980, all produced waters generated in Alabama were from conventional deep-well sources and were disposed by underground injection through the State's Underground Injection Control Program. The first NPDES permit (National Pollutant Discharge Elimination System) issued for disposal of coalbed produced waters allowed surface discharge via land application or stream discharge because the salinity of these waters were much lower compared to the conventional produced waters (O'Neil et al. 1992). These original discharge permit limits were derived primarily from coal surface mine criteria and regulated upstream concentrations of total dissolved solids, effluent concentrations of irons and manganese and $\mathrm{pH}$ and implemented by the Alabama Department of Environmental Management (ADEM). While ADEM was implementing these discharge limits, the U. S. Environmental Protection Agency (EPA) was introducing a new policy direction for control of surface discharge effluents. The new policy stipulated that regulation of surface discharge effluents was to be technology and water quality-based. The latest edition of Technical Support Document (TSD) for water quality-based control of effluents 
(USEPA 1991) recommends three levels for controlling effluent discharged to surface waters. These three levels are chemical specific (water quality criteria) controls, aquatic toxicity testing and instream monitoring of biological populations (biomonitoring). Each level of control is considered by the EPA equal and any negative response from any level (either exceeding water quality criteria, demonstrating toxicity or impacting stream populations) would require action from the permittee to regain compliance of their effluent with permit limitations (O'Neil et al. 1992). The produced waters are currently disposed of either by land application or stream discharge (O'Neil et al. 1992).

\section{Water Quality Criteria}

Produced water discharge permits in Alabama are written on the basis of either chemical or parameter-specific criteria not to be exceeded or on the basis of mass quantities of material that may be discharged over specific time periods. Permits written for streams have criteria specific requirements (Tier I) while permits written for large rivers are on mass discharge basis (Tier II). Chemical-specific criteria are written as: dissolved oxygen (>5.0 $\mathrm{mg} / \mathrm{L}) ; \mathrm{pH}(6.0-9.0)$; total dissolved iron $(3.0 \mathrm{mg} / \mathrm{L}$ monthly or daily average $6.0 \mathrm{mg} / \mathrm{L}$ daily maximum); total dissolved manganese $(2.0 \mathrm{mg} / \mathrm{L}$ or daily average, $4.0 \mathrm{mg} / \mathrm{l}$ daily maximum); biochemical oxygen demand $(30 \mathrm{mg} / \mathrm{L}$ monthly or daily average, $45 \mathrm{mg} / \mathrm{L}$ daily maximum); and total dissolved chloride ( $230 \mathrm{mg} / \mathrm{L}$ monthly or daily average, $860 \mathrm{mg} / \mathrm{L}$ daily maximum). Response levels for chloride is usually in the range of 150 to $200 \mathrm{mg} / \mathrm{L}$. 
Mass discharge (lbs/day) calculations are based on the 7-day, 10-year low flow (7Q10) and the average chlorides reported for wastewaters. All permits are written specifically for a produced water effluent under application and most contain the above criteria as a minimum. Some permits may require additional chemical-specific criteria for selected trace metals if data for the wastewater and receiving stream support such a stipulation (O'Neil et al. 1992).

\section{Water Production}

Total water production from the 3,089 gasification wells in the Black Warrior Basin was $106 \mathrm{MM}$ bbls in 1992 and Cumulative water production from the field was approximately $266.3 \mathrm{MM}$ bbls of water in 1992 . Water production is usually high during the initial dewatering stages of gas wells (GRI Quarterly Review February 1993).

\section{Water Quality}

Produced water effluents from the northeastern parts of the coalbed degasification fields in Alabama range from approximately 1,500 to $5,000 \mathrm{mg} / \mathrm{L}$ total dissolved solids (TDS). According to Hem's (1989) ranking, this concentration range is slightly to moderately saline. Produced waters from the southwestern degasification fields range from approximately 15,000 to $22,000 \mathrm{mg} / \mathrm{L}$ TDS. These waters are ranked as very saline and approach the concentration of sea water ( $>35,000 \mathrm{mg} / \mathrm{L}$ TDS). The major contributors to 
TDS in coalbed produced waters are sodium and chlorides. Chlorides in waters in the southwestern part of the fields range from 8,000 to $15,000 \mathrm{mg} / \mathrm{L}$ while the range in the waters from the middle region coal fields is $500-2,000 \mathrm{mg} / \mathrm{L}$. Coalbed produced waters in the very northeastern part of the Warrior Basin have a very low salinity and some approach the TDS concentration of receiving streams in the area (O'Neil et al. 1992).

The $\mathrm{pH}$ of coalbed methane produced waters typically range from 7.5 to 9.0 with most waters between 8.0 and 8.5 . These waters are highly buffered with carbonate ranging up to $100 \mathrm{mg} / \mathrm{L}$ and bicarbonate ranging from approximately 200 to $1,000 \mathrm{mg} / \mathrm{L}$. High concentrations of calcium and magnesium, particularly in the southwestern part of the region result in very hard waters.

Detectable concentrations of trace heavy metals such as arsenic, barium, lead, strontium and zinc are also contained in coalbed methane produced waters in Alabama (O’Neil et al. 1989).

\section{Pretreatment Before Discharge}

Most waters produced from coalbed methane operations in the Black Warrior Basin are pretreated to the standards described above. Current pretreatment methods typically include short-term storage and in-stream dilution (Luckianow and Hall 1991). 


\section{ACKNOWLEDGEMENT}

The author expresses thanks to the United States Department of Energy (DOE) for funding this work. The grant was awarded to Jack W. McIntyre under DOE Contract No. DE-FG46-92R699202. Mr. McIntyre contracted Geraghty \& Miller to perform the research. Special thanks go to Robert Miller, Hugh Robotham and Sandra Elliott for editing and reviewing this paper. Thanks to Carol Ballard for the extensive work processing needed for this document. 


\section{REFERENCES}

Beg, M.A., Daniel, T.W., Clarke, O.M., Kidd, J.T. and Massingill, J.H.. "Mineral Resources of Tuscaloosa County, Alabama", Geological Survey Alabama Special Map 185, 78 p, 1978.

Bolland, L.F. and Minihan, E. D. "Petroleum Potential of the Black Warrior Basin", Gulf Coast Association of Geological Societies Transactions, vol. 21, pp 139-158, 1971.

Butts, C. "The Paleozoic Rocks in Geology of Alabama", Edited by G. A. Adams, C. Butts, L. Stephenson, and W. Cooke: Geological Survey of Alabama, Special Report No. 14, pp 40- 223, 1926.

Culbertson, W.C. "Geology and Coal Resources of the Coal Bearing Rocks of Alabama", U. S. Grological Survey Bulletin 1182-b, 79 p, 1964.

Epsman, M.L., Wilson, G.V., Pashin, J.C., Tolson, J. S., Ward, W.E. II, Chandler, R.V., Winston, R.B., Richter, K.E., Hamilton, R.P. and Rheams, L.J. "Geologic Evaluation of Critical Production Parameters for Coalbed Methane Resources, Part 2-Black Warrior Basin", GRI Annual Report. GRI-88/0332.2, 178 p, August 198\%-July 1988, 1988.

Ferguson, C.C. and Stearns. "Stratigraphy and Petrology of the Upper Mississippian of Southernmost Tennessee", in A field Guide to Mississippian Sediments in Northern Alabama and South-Central Tennessee, Alabama Geological Society 5th Annual Field trip Guidebook, pp 53-60, 1967.

Flawn, P.T., Goldstein, A., King, P.B., and Weaver, C.E. "The Ouachita System", Texas Bureau of Economic Geology, Publ. 6120, pp 94-98, 1961.

Gas Research Institute Quarterly Review of Methane from Coal Seams Technology, 1987.

Gas Research Institute Quarterly Review of Methane from Coal Seams Technology, pp 4-5, April 1993.

Hewitt, J.L. "Geologic Overview, Coal, and Coalbed Methane Resources of the Warrior Basin Alabama and Mississippi", Coalbed Methane Resources of the United StatesAAPG Studies in Geology Series \# 17, pp 73-104, 1984.

Hem, J.D. "Study and Interpretation of the Chemical Characteristics of Natural Water", United States Geological Survey Water Supply Paper 2254, 263 p, 1989. 
Kidd, J.T. "Configuration of the Top of Pottsville Formation in West-central Alabama", State Oil and Gas Board, Geological Survey of Alabama, Map 1, 1976.

Kruuskraa, V.A., Boyer, C.M. II and Kelafant, J.A. "Hunt for Quality Basins Goes Abroad", Coalbed Gas-1, Oil and Gas Journal, October 5, 1992.

Luckianow, B.J. and Hall, W.L., "Economics of Production Water Storage", Proceedings of the 1991 Coalbed Methane Symposium, The University of Alabama/Tuscaloosa, pp 57-68, May 1991.

McCalley, Henry. "On the Warrior Coal Field", Geological Survey of Alabama Special Report No. 1, 571 p, 1886.

McCalley, Henry. "Report on the Warrior Coal Basin", Geol. Survey Alabama Spec. Report 10, 327 p, 1900.

Melici, R.C., Brent, W.D. and Walker, R.K. "Depositional Environments in Upper Conasauga Lagoon-Fill Sequence", in "Geology of Knox County, Tennessee", Tennessee Division Geology Bulletin 70, pp 138-148, 1973.

Mellen, F.F. "What's Ahead for the Black Warrior Basin?", World Oil, 173, No 2, pp 45-53, 1971.

Mellen, F.F. "Black Warrior Basin, Alabama and Mississippi", Bulletin of the American Association of Petroleum Geologists, vol. 31, No 10, pp 1810-1816, 1947.

Murrie, G.W., W.P. Diamond and S.W. Lambert. "Geology of the Mary Lee Group of Coalbeds, Black Warrior Coal Basin, Alabama", U. S. Bureau of Mines Report of Investigations 8189, $49 \mathrm{p}, 1976$.

O'Neil, P.E., Harris, S.E., Drotter, K.R., Mount, D.R., Fillo, J. P. and Mette, M.F. "Biomonitoring of a Produced Water Discharge from the Cedar Cove Degasification Field, Alabama", Gas Research Institute Final Report, GRI-89/0073, 195 p, June 1989.

O'Neil, P.E., Isaacson, H.R. and Evans, J.M. "Surface Discharge of Coalbed Methane Produced Waters in the Warrior Basin of Alabama, the Cedar Cove Model", in Produce Water, ed. J. P. Ray and F. R. Engelhart, Plenum Press:NY, 1992.

Pashin, J.C., Chandler, R.V. and Mink, R.M. "Geologic Controls and Occurrence and Producibility of Coalbed Methane, Oak Grove Field, Black Warrior Basin, Alabama", Coalbed Methane Symposium Proceedings, University of Alabama, Tuscaloosa:School of Mines and Energy Development, Gas Research Institute, U. S. Mine Safety Health Administration, and Geological Survey of Alabama, pp 203-209, April 1989. 
Self, D.L. and Neathery, T.N. " Lexicon of Structural Features in Alabama", University of Alabama, Geological Survey of Alabama and U. S Geological Survey, p 496, 1975.

Thomas W.A. "Mississippian Stratigraphy of Alabama", Geological Survey of Alabama, Monograph 12 pp 121, 1972.

Thomas, W.A. and Hines, R.A. "Primary Geologic Controls on Coalbed Methane Content", University of Alabama School of Mines and Energy Development Research Report 72, 1985.

Thomas, W.A. and Mack, G.H. "Paleogeographic Relationship of a Mississippian BarrierIsland and Shelf-bar System (Hartselle Sandstone) in Alabama to the AppalachianOuachita Orogenic Belt", Geological Society of American Bulletin, vol. 93, pp 6-19, 1982.

Thomas, W.A. and Womack, S.H. "Coal Stratigraphy of the Deeper Part of the Black Warrior Basin of Alabama", Gulf Coast Assoc. Geol. Societies Trans.vol 33, pp 439 446, 1987.

Thompson, D.A. and Hertz, W.J. "Utilizing the Unconventional Gas Resources of the Pottsville Formation Coals in Tuscaloosa County, Alabama-Feasibility Study for the B. F. Goodrich Company", University of Alabama School of Mines and Energy Development Research Report, 45 p, 1982.

Thompson, D.A. and Telle, W.R. "Coalbed Methane in the Black Warrior Basin, Alabama Geology, Resources, and Development", Gas Research Institute Quarterly Review of Methane from Coal Seams Technology, February, 1987.

Ward, W.E. II, Drahovzal, J. Jr. and Evans, F.E. "Fracture Analyses in a Selected Area of the Warrior Basin, Alabama", Geologic Survey Alabama Circ. 111, pp 78, 3 pls., 1984. 

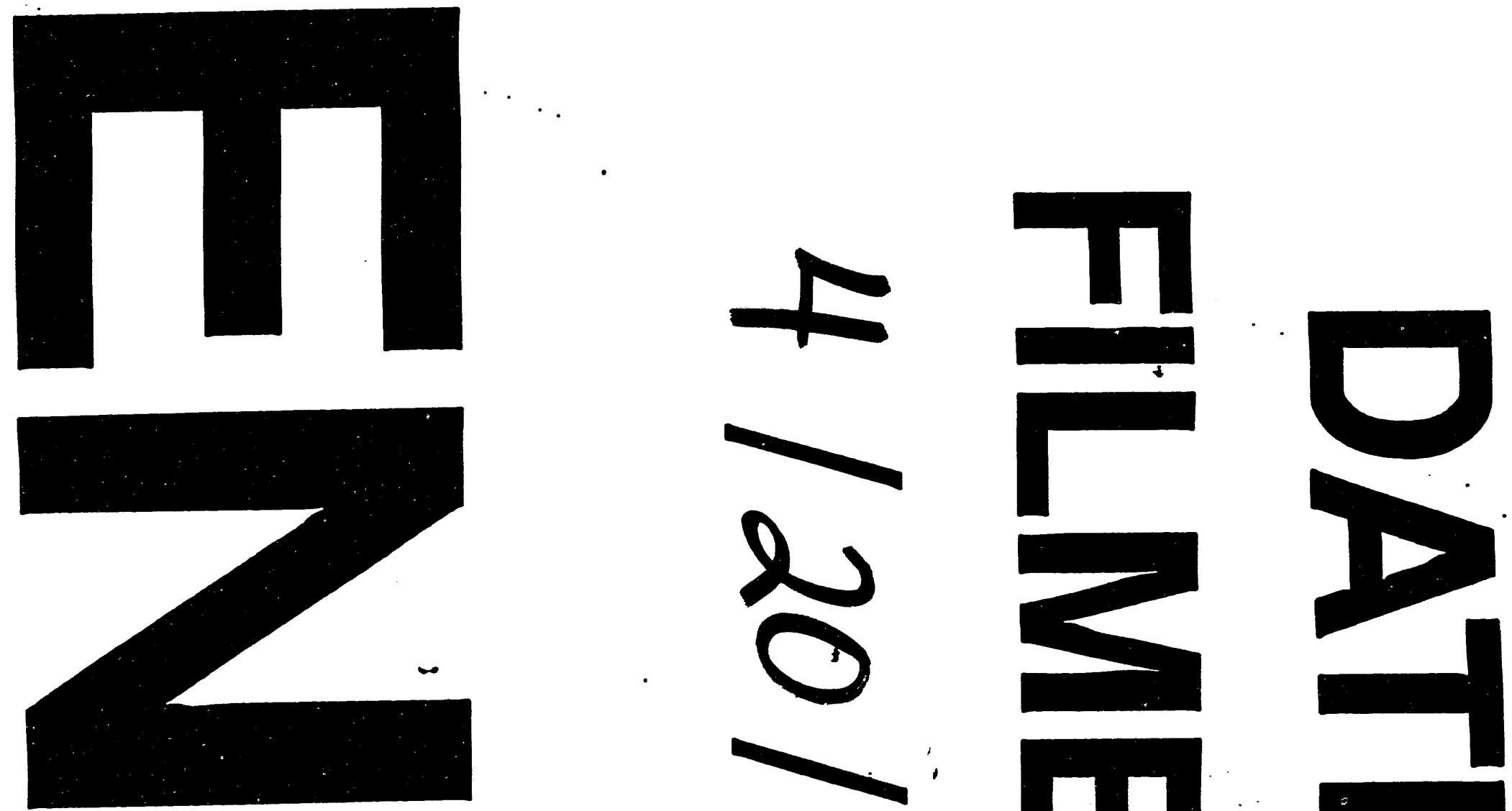

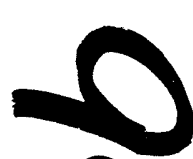
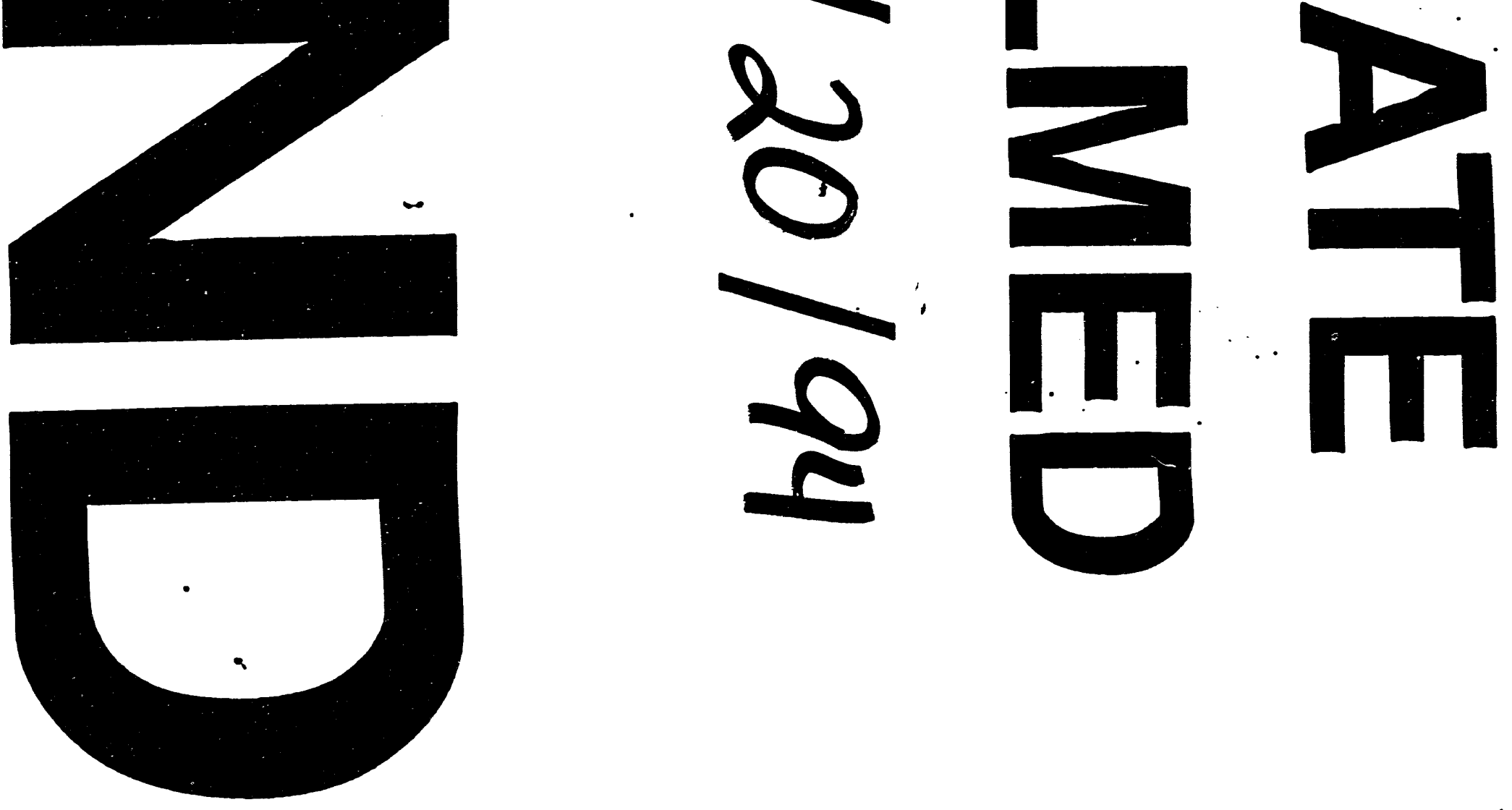


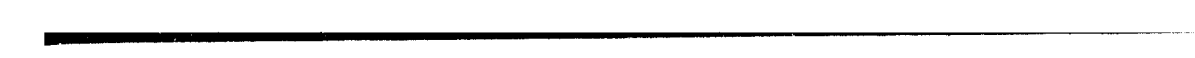

